\title{
Enhancing Speaking Skills in the Material of Remedial Learning Through Community Language Learning in SMP Multazam Semarang
}

\author{
Muhamad Zayyinul Muttaqin \\ Multazam Junior High School in Semarang \\ ziiaiant891@gmail.com
}

\begin{abstract}
This paper highlighted how extremely English language learning that sometimes seemed threatening pupils in the classroom where they were unable to express much attention and confidence. They quantitatively got the worst score for this subject due to several aspects that must be comprehended by students: pronunciation, grammatical structure, vocabulary, and intonation. As long as, students participated in the teaching-learning process, they had standardly done all of the assessment. Therefore, teachers here as the facilitator or counselor should redesign the classroom's atmosphere and its method; instead, it would invite students to show their best performance. Community Language Learning (CLL) displayed how effectively and efficiently English should be taught. Thus, this research is qualitatively reported to observe how CLL was able to increase the students' speaking skill in the Material of Remedial Learning for students' eight grade in SMP Multazam with the total number of 26 students. An observation sheet and the score ranking sheet were as data collection to consider the names. A fluency, a pronunciation, an expression, a vocabulary, and content were the instrument to analysis their performance. This study was Classroom Action Research which revealed that the students are comfortable in joining learning's experience, and its effects to their competence in speaking skill with the amount of enhancement through 2 cycles; post-test 1 and post-test 2 . CLL was considered to be an effective method since it contributed to the prominent effect of speaking skill.
\end{abstract}

\section{ARTICLE HISTORY}

Received 9 February 2019

Accepted 30 April 2019

\section{KEYWORDS}

Community language learning; speaking skill; and material of remedial learning

\section{Introduction}

It is well-known that English is generally spoken by most humans as their media to transfer the intentions: giving services and asking for something. Therefore, Mastering English, either spoken or written form, is required for each person for having a clear and good interaction. Instead, English materials are specifically involved in Indonesian's curriculum in order to create the easiest way to push students' attention and interest in learning English; as, the primary aims of gaining of English skills are to achieve and to produce students' ability either spoken or written in English (Alimi, 2015, p.6). 
Moreover, (Alimi, 2015) claims that spoken product as the major consideration that had better be developed gradually. On the other hand, speaking skill is considered as humans' necessary to show their ability to have a great interpersonal toward persons' answers and questions. So, speaking ought to be learned for every single pupil in the classroom since it was the concert identity for English speakers.

Here, the supportive study, in case of enhancing students' speaking skill, was conducted by (Sari \& Syarfi, 2014) had already succeeded to solve a basic problem in the classroom. The study highlighted the improvement of speaking skill through Community Language Learning, it obviously helps students to be more active and aware; the result showed through a speaking test, observation sheet, and field note could improve the students' behavior and its' competence in speaking skill.

In fact, producing utterances are being hard and challenging when the students are asked by a teacher to share their ideas about certain topics in front of the class. They face various mistakes which make them having poor categories of good English speaking skill. According to (Sari \& Syarfi, 2014,p.3) that students realize in which speaking's roles need more preparations: well-pronounced should be clear for each English class, it must be produced in grammatically correct, a good expressive and bodily language, text and context is richly vocabularies and high confidence.

Therefore, for those students who got a worse score had better take remedial learning to strengthen their achievement. In this case, the teacher needs to implement an appropriate method and media to achieve their target aims for the current topic. Community Language Learning (CLL) services how ideally language (in a speaking process) should be learned by designing teacher as students' counselor, and it might encourage students to be motivated in learning English.

As consideration above, the researcher would like to apply CLL as the method to make an influence for enhancing the student's speaking skill for those students who are involved in remedial learning in SMP Multazam IBS in academic year 2018/2019 for eight grade.

\section{Community Language Learning (CLL)}

Community Language Learning (CLL) rudimentary advises educators for utilizing learning management as the basic approach to mastering how exactly English is taught or mastered, so pupils seem to comfort and they can afford all material without any problem. CLL construes that learning English should be considered as the part to enhance students as the 'whole persons', it means that counselor here not only focus on how students learn, but also how they develop their capability to have high desire, good relationship, and good activeness (Larsen-Freeman \& Anderson, 2002, p. 91).

Larsen and Freeman argue (2002) why CLL is placing teachers here as counsellors because the term 'counselor' becomes the deal way to minimize pupils' 
fear, or it means that English counsellors are persons with skillful teachers of the struggle students face as they attempt to internalize another language. Here, the counselors are asked to be professional in understanding students' acceptance either they feel fear or they don't. In addition, By understanding students' fears and being sensitive to them, the counselors had better be ready in assisting or overcoming their negative feelings of pupils.

CLL integrates both a cognitive and affecting in human learning to gain the target language where students gather in one place to do several activities and its tasks while counselor facilitate them (Nagaraj, 2009, p.177), here as follow;

1. A group task, learners involve in a small group with their various task; preparing a conversation, preparing a summary of a topic for presentation to another group.

2. Tape recording students' conversation, this technique is used to give students' chance for recording their voice in a target language while they in a conversation.

3. Transcription, this process, learners officiate to transcribe their utterances and conversation that they already recorded through a tape recorder, then counselor writes them on a whiteboard.

4. Students' reflection, after challenging through all duties, pupils ought to share their opinion on how they feel about their language learning experience.

5. Listening reflection, the students' are asked to listen together with others to the English monologue while counselor reads students' transcription.

Those are five types of students' work in CLL's form which is required pupils to be active. Furthermore, (Curran, 1976, p .105) in (Larsen-Freeman \& Anderson, 2002) claims that the learners who pass the five stages of CLL's task will bring them to advance language learners.

\section{Speaking Skills}

A term 'speaking' in the English Language Teaching (ELT) has been defined by many authors and scientists. (Harmer, 2001) states that speaking as a tool to recovery for expressing humans' command and service in certain types of oral tasks. (Nunan, 1999) defines that "Speaking is called as the way to convey verbally to do a clear communication either for a transactional or an interpersonal goal." In addition, (Alimi, 2015, p. 23) argues some people do the communication for their personal needs either in transactional or interpersonal process.

On the other hand, (Mel, 2011) describe the term 'Speaking' and its function;

Speaking involves a lot more than just using grammar and vocabulary accurately in speech. When we speak, we constantly have in mind the person we are speaking to and our wish to communicate our meaning successfully to them. We use interactive strategies to help us achieve this. These include using body languages such as gestures, eye contact, facial expression, and movement to put our message across more strongly and clearly, and functions such as 
clarifying our meaning (..), asking for opinions (...), agreeing (...) to keep the interaction (communication) going and check that is successful. (p. 48-49)

Speaking here as the major skill to get the good and meaningful interaction each speaker, this process sometimes involves in some part communication; formal or informal dialogue, selling and buying conversation, or joking. Certainly, it needs more than confidence but how to communicate clearly by showing good attitude, sufficient face's expression, and good bodily gestures.

One of four elements of English skills is speaking skill which refers to the ability to express the humans' mind through sound or utterance then it is called a productive skill. As stated by (Chastain, 1988) that speaking is claimed as a productive skill which includes many components. In addition, (Tarigan, 1981) argues that speaking is the capability to produce a sound to express such ideas or feelings.

Furthermore, speaking proficiency belongs to how language is accurately produced with a number of factors, that why speaking skill is regarded as the complicated features, as classified as follow by Harris (1974);

1. Pronunciation; it covers whether vowel, consonant, stress, and intonation of a pattern are included in students' utterance so that they are categorized as a foreign accent.

2. Grammar, it aims to show the ability to use the grammatically correct in every sentence.

3. Lexis; the much speakers use several of vocabularies the highest sentences will be meaningful. The selection of correct vocabs is needed for every single speaker to make a clear conversation.

4. Fluency; this is an aspect expresses either speaker good in communication or does not He or She. It means the term 'fluency' is used for the persons who are accustomed to utter daily in English.

\section{The Material of Remedial Learning}

According to assessment standard No 23: 2016, Material of remedial learning belongs to student/s who haven't passed, yet the minimum score of the material of regular learning in certain topics. It doesn't mean, the pupils who get the lower score from a subject's minimum score they were allowed to join the extra or additional materials. Different from for those students who have already passed the minimum score then they are required to involve the extra or enrichment material.

Moreover, each teacher has to able to conduct an assessment to know and measure the students' quality, and based on assessment standard about the way teachers deliver assignment through cognitive and skill valuation. A cognitive assessment involves oral and written test such as making a summary of the topic, 
doing multiple choice or essay, or observation while skill assessment includes project, practice, product, or portfolio.

\section{Research Methodology}

This study refers to classroom action research (CAR) since it aims to give an enhancement of the way teaching and learning method to be developed through some cycles. According to (Kemmis, McTaggart, \& Nixon, 1998) Classroom Action Research is conducted through several cycles process; planning, action, observation, and reflecting, one cycle of those four actions is determined as the strategy to solve the problems in the teaching-learning process. Additionally, (Jone, 1983) defines 'Classroom Action Research" as the process of enhancement for classroom activities which are done by some professional practitioners.

The participants of this study were the students of SMP Multazam IBS Semarang in academic year 2018/2019. The total numbers of the participants were 26-grade students who haven't completed or reached the minimum score that was 70 . They were unaffordable for practicing the skill's assignment (speaking) on basic competence 1, and they were assessed through some categories; fluency, pronunciation, expression, vocabularies, and content.

The instrument of this study was speaking skill in the form of dialogue which was highlighted four sub-topics, they were; getting attention, checking to understand, appreciating someone' performances and asking for an opinion. Then, the researcher observed the way pupils delivered their performance with an observation sheet and followed by giving a score for each student. Those were procedures in conducting this research as the form of an instrument before applying Community Language Learning.

Furthermore, after implementing a speaking test, the researcher got the names of students who were required to join a remedial program. Furthermore, the researcher applied CLL to teach in a remedial program with few topics which were not be mastered by pupils. Finally, the researcher conducted the post-test to measure whether pupils had already comprehended the substantial matters or the students had not yet.

\section{Findings And Discussion}

Based on the findings, the researcher found the improvement of students' ability in speaking skill through implementing CLL method. The evidence could be observed as follows; 
Table.1 The improvement of students' speaking skill from pre-test to post-test 2

\begin{tabular}{llll}
\hline Ability level & Pre-test & Post-test 1 & Post-test 2 \\
\hline Excellent & $0.00 \%$ & $0.00 \%$ & $11.54 \%$ \\
\hline Very good & $23.08 \%$ & $42.31 \%$ & $69.23 \%$ \\
\hline Poor & $79.92 \%$ & $57.69 \%$ & $19.23 \%$ \\
\hline Very Poor & $0.00 \%$ & $0.00 \%$ & $0.00 \%$ \\
\hline
\end{tabular}

The table above, pre-test to post-test 2 , was also presented the improvement of students' speaking ability through chart:

Chart. 1 The improvement of students' speaking skill from pre-test to post-test 2

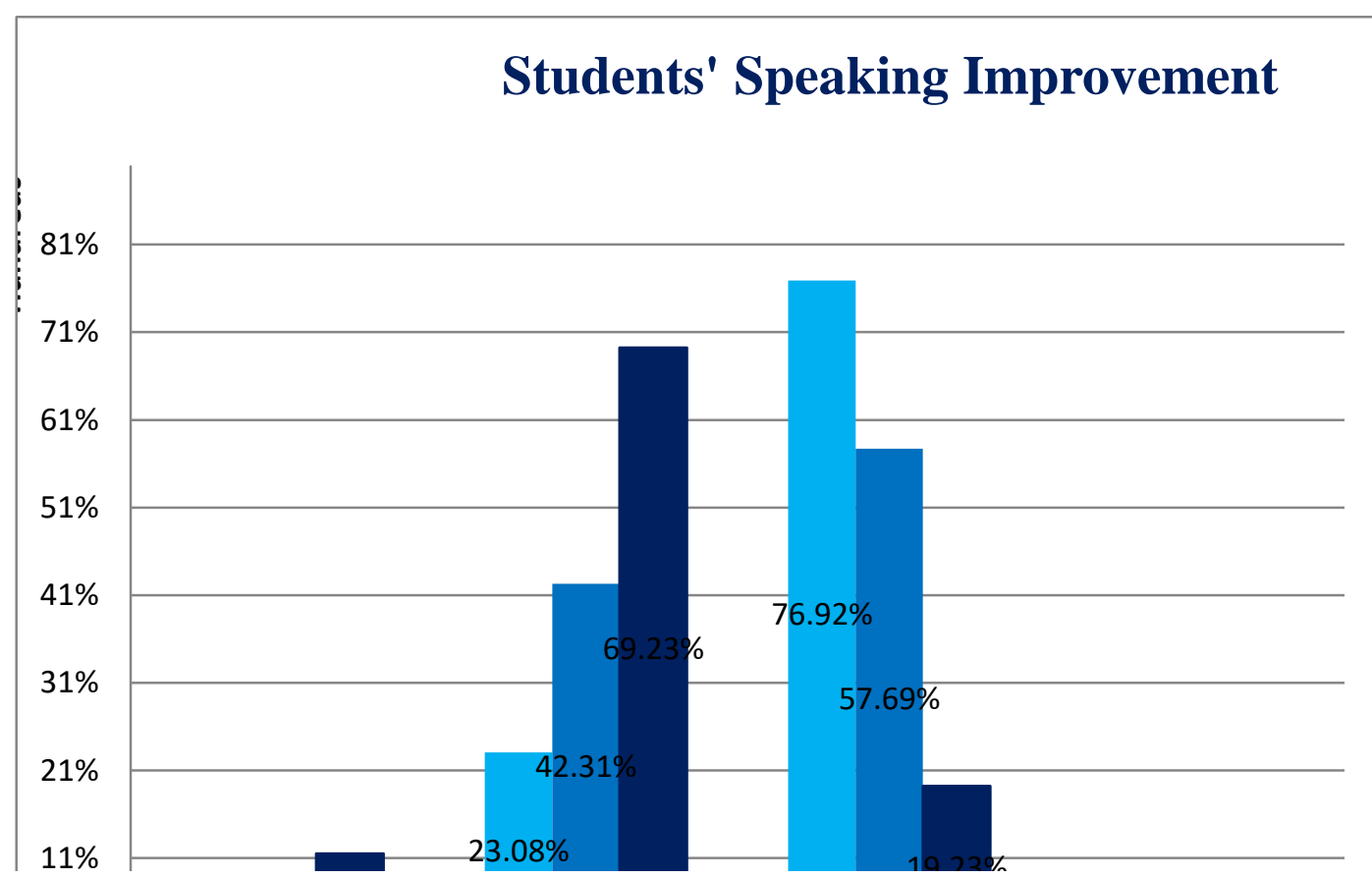

The data above clearly showed some cycles of improvements from pre-test up to post-test 2 . In pre-test stage, students' are typically examined through a speaking test with amount number of participants are 26 students; they are in "Poor" level $(79.92$ $\%)$ and "very good" level (23.08\%). On the other hands, some students were so much lack of speaking skill as they were not in "an excellent" level.

However, after implementing CLL in teaching speaking, there were many changes: the students who were in poor level $(79.92 \%)$ became $(57.69 \%)$ in post-test 1 , it meant that there were influences to students' result. Level "very good" was also changing from $23.08 \%$ to $42.31 \%$. In post-test 2 was the final result of students to be examined by using CLL. Here some transformations happened, several students 
were in "Excellent" level (11.54\%), then followed by "Very good" level that was $(69.23 \%)$ and for the "Poor" level was fewer, (19.23\%), than two both levels.

Unlike, the following table was the result of learning achievement, from pretest to post-test 2 , through speaking assessment.

Table. 2 The Improvement of Students of each Aspect

\begin{tabular}{llll}
\hline Ability level & Pre-test & Post-test 1 & Post-test 2 \\
\hline Pronunciation & $15.86 \%$ & $21.58 \%$ & $22.36 \%$ \\
\hline Fluency & $17.42 \%$ & $21.32 \%$ & $26.52 \%$ \\
\hline Expression & $15.86 \%$ & $20.02 \%$ & $20.54 \%$ \\
\hline Vocabulary & $21.06 \%$ & $23.66 \%$ & $26 \%$ \\
\hline Original Text & $31.76 \%$ & $31.98 \%$ & $32 \%$ \\
\hline
\end{tabular}

There were five elements which could obviously found in the instrument of speaking which the author objectively conduct from pre-test to post-test 2. Earlier, 26 students felt tough to achieve those items, therefore the author applied CLL. Five elements: first, the pronunciation was too weak to do; unfortunately, the leaners accomplished $15.86 \%$ in the first meeting. Then, after implementing CLL, they got $21.58 \%$ as their post-test 1 and enhanced, in post-test 2, to $22.36 \%$. Second, fluency, as speaking test dealt with a meaning of the content as well as the students, here, were so confusing. They achieved $17.42 \%$ in pre-test then followed by post-test 1 with $21.32 \%$ as their score and $26.52 \%$ for the last grade.

Expression was, as the third aspect, assessed through post-test 1 and 2 as their achievement was too low, that was $15.86 \%$. Continuously, there were improvements in post-test 1 to 2 that was $20.02 \%$ to $20.54 \%$. The fourth dealt with vocabulary that occasionally was better than three aspects before. The leaners were very enthusiastic in using varieties vocabularies, they got $21.06 \%$ for their first test, then followed post-test 1 and 2, they were $23.66 \%$ to $26 \%$. An original text as the last aspect that might be assessed, the result objectively showed that leaners had already in adequate expert in shaping the topics. They got $31.76 \%$ in pre-test then $31.98 \%$ as post-test 1 , and post-test 2 , they achieved $32 \%$.

Next, the researcher also displayed the following chart as the visual data to present the improvement of a student of each aspect; 
Chart. 2 The development of students' speaking in each aspect

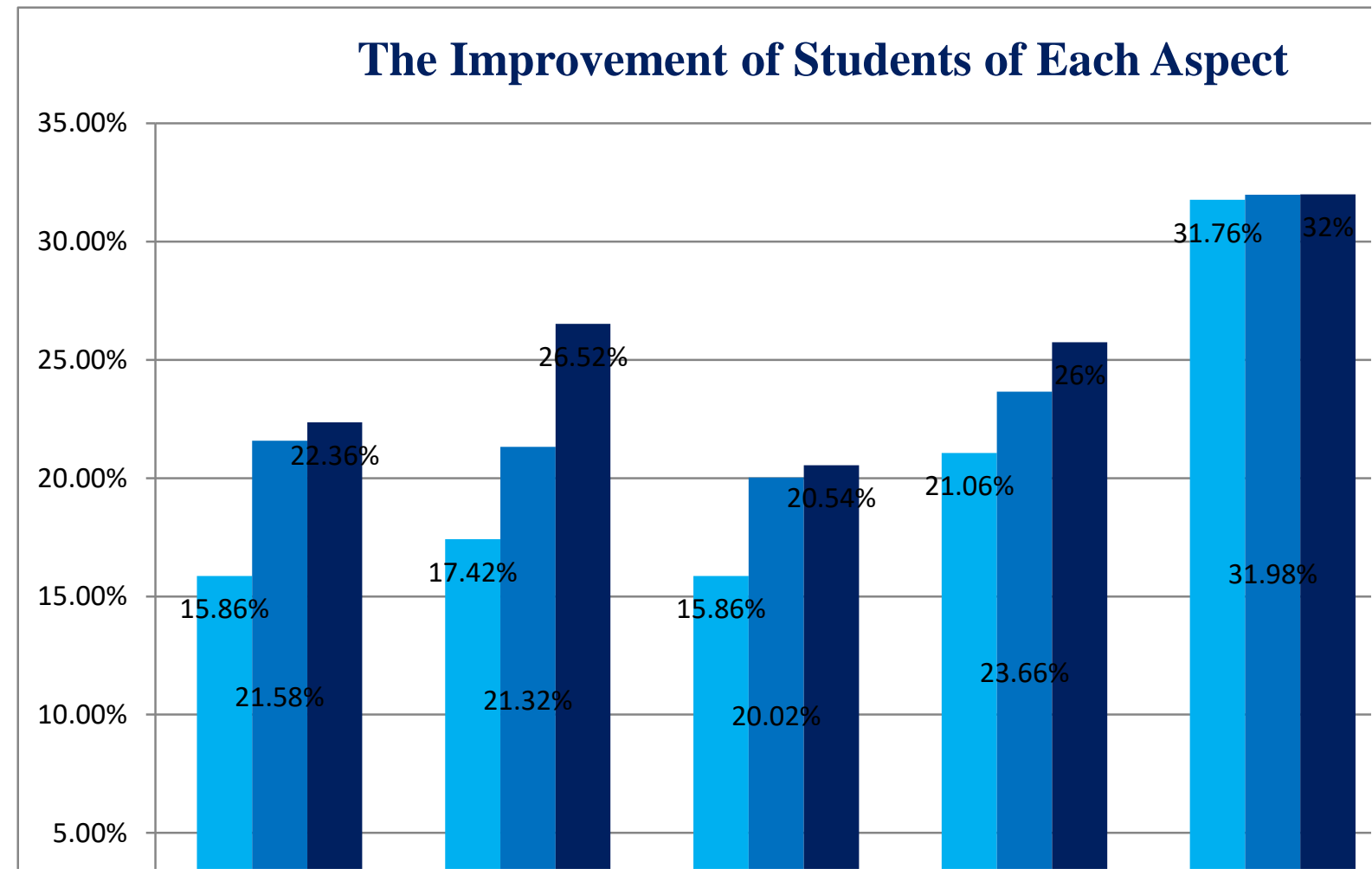

Simply, this method was objectively applied to teach students in a speaking area; it gave some contributions to develop students' competence especially when it was implemented in SMP Multazam Semarang. Students now were really enjoying to practice confidence by using English utterance. Therefore, the author, surely, could conclude that CLL method was able to influence students' serious problems.

\section{Conclusion}

The proposed intention by conducting this study to investigate whether implementing CLL to enhance students' ability for speaking skill could be realized. It could be seen from the evidence: First, an applying CLL, in fact, could be realized meanwhile it caused to students' performance and their behavior. The data above (see table 1) was the evidence that CLL carried out an important aspect to be continued or applied in teaching speaking skill.

Second, this strategy was efficient to improve students' speaking ability as follows: most of the students can express their idea, opinions freely and most of the students can work in group freely. As a result, they were getting more confidence and interaction in speaking class. Teaching speaking through Community Language Learning was a way to enhance motivation, and it could stimulate students to use their newly-acquired English. So, English teachers were expected to give the students a lot of chance to speak in an everyday classroom learning process. 


\section{Suggestion}

Regarding the discussion above, the author briefly accommodates some suggestions for further study, as follows;

1. As this method was categorized as an effective method to be used in enhancing students' speaking skill in a classroom, it will be alternatively applied for further teaching process by English teachers.

2. English teachers are required to continuously implement this method to motivate students' behavior and their attitude to achieve especially for speaking mode.

3. It will be useless to be meaningful since students are not aware to be active in any performance. Therefore, the learners are obviously demanded to show their attention toward some teaching process

4. For further researches, the authors might significantly cover different kinds of objects or interesting English area through Community Language Learning as it offers an accepted result to develop speaking aspects. 


\section{References}

Alimi, B. (2015). Enhancing Students 'Speaking Skill through Cooperative Group Work Technique. (June).

Chastain, K. (1988). Developing second-language skills: theory and practice. Harcourt Brace Jovanovich.

Curran, C. A. (1976). Counseling-Learning in Second Languages. Retrieved from https://eric.ed.gov/?id=ED146804

Harmer, J. (2001). How to teach English. Pearson Longman.

Jone, C. (1983). A Searching Profession? The Growth of Classroom Action Research. Scotland: Moray House College of Education.

Kemmis, S., McTaggart, R., \& Nixon, R. (1998). The action research planner : doing critical participatory action research. Victoria: Deakin University Press.

Larsen-Freeman, D., \& Anderson, M. (2002). Techniques and principles in language teaching. Oxford: Oxford University Press.

Mel, P. (2011). Spratt, Mary Pulverness, Alan Williams, Melanie. Cambridge: Cambridge University Press.

Nagaraj, P. (2009). Application of Community Language Learning for Effective Teaching. MJAL.

Nunan, D. (1999). Second language teaching \&amp; learning. Boston: Heinle \& Heinle Publishers.

Sari, N. K., \& Syarfi, M. (2014). The Use of Community Language Learning Method to Improve Speaking Ability of the Second Year Students of SMP Muhammadiyah 2 Pekanbaru.

Tarigan, H. G. (1981). Berbicara sebagai suatu keterampilan berbahasa / Henry Guntur Tarigan. In 1. BERBICARA,Berbicara sebagai suatu keterampilan berbahasa / Henry Guntur Tarigan. Retrieved from http://library.um.ac.id/freecontents/index.php/buku/detail/berbicara-sebagai-suatu-keterampilanberbahasa-henry-guntur-tarigan-34553.html 